\title{
Does World Cinema Really Exist? - Derivations Of World Cinema
}

\author{
Aneek Chaudhuri
}

\begin{abstract}
The world has become globalized now, although, the true meaning of globalization is still vague. With the accumulation of more and more power to the Westernized nations, as the synonym of United States, the concept of global conglomeration has been applied to practicality, ultimately. In this paper, without going into a debatable angle, will discuss the existence of World Cinema, and what does it really mean in the context of crème or quality filmmaking.
\end{abstract}

Keywords: globalized, global conglomeration, technical, Identification and Justification

\section{Introduction}

If we go by the technical usage of the term 'World Cinema', it refers to the movies that are made in non-English speaking countries. But, it is partially applicable. Since 1895, and till today, Cinema has been the play for Americans, or American directors. Hollywood has been ruling such a play from decades where filmmaking has not only cultivated a sophisticated standard of filmmaking, it has also started influencing other countries, as well. But, at the same time, Europeans enhanced a kind of Cinema which was aesthetically and intellectually, much more creative than American Cinema. Slowly, Cinema had started gaining a flash of qualitative fame in parts of Asia, say Japan, Iran, and India. And soon, it was the emergence of Akira Kuroshawa, Takeshi Kitano, Majid Majidi, Mohsen Makhmalbuf, Satyajit Ray, RitwikGhatak and so on. Thus, came to be known as World Cinema; the movies that represented the world, without being shaded by a fear of being 'influenced'.

But, are all films made outside U.S., a part of World Cinema?

\section{Derivatives Of World Cinema}

Three derivations of World Cinema will be considered in this paper. They are:

- Identification and Justification of World Cinema

- Qualitative aspect of World Cinema

- Commercialism as a threat to World Cinema

\subsection{Identification \& Justification Of World Cinema}

World Cinema also sounds quality work, as it is something that is (almost) opposition to the Hollywood movies. Therefore, films should be worth the quality, to compete at the International level. Whereas, films were made in U.S. with a prescribed format of filmmaking, other countries were involved in experimental cinema; it paid off quite well. Now, let's get into details.

Suppose, one has to shoot a scene where a couple is making love, and the bed gets callously caressed with the couple's feet. And soon, the audience explores something else. If a Hollywood director is shooting the scene, he would employ a 'Bird's eye view shot', where the viewer is unclear about the persons involved in such a passionate affair. Henceforth, the camera would scroll down orZoom-in to the face of the couple. But, what does one discover? The girl is with someone else i.e. not with her supposed partner. We can call it either commercialism, or the Hollywood pattern of filmmaking, where storyboards are created according to a copybook format.

Now, we will discuss a Truffaut's way or Kieslowski' picturesque mannerism.

If the same scene is shot by the above mentioned directors, firstly a mirror would have been placed which reflects the couple. In the beginning, the man's face would be unclear. The girl is supposedly in a passionate mood. All of a sudden, when the man rises up (partially), his face gets clearly reflected in the mirror. The girl tries to resist the temptation and accidentally, breaks the mirror glass. Now, the man's face can be seen demolished in the mirror, with some drops of ink falling over the glass. This is known as artistic filmmaking, where a scene depicts something more than just shooting a scene. Over the years, World Cinema has gained popularity among a certain section of audience, considering its intellectual interpretation.

What about Britain? Is it a part of World Cinema, going by its technical description, or shall we follow the latter justification? 


\section{Cinema in Britain: Is it a part of World Cinema?}

In this section, British Cinema will be defined in two parts that justifies it for not being a part of World Cinema. What are they?

Firstly, a statement by Satyajit Ray, clearly differs British Cinema from Hollywood:

"I do not think British are temperamentally equipped to make the best use of the movie camera. The camera forces one to face facts, to probe, to reveal, to get close to people and things; while the British nature inclines to the opposite: to stay aloof, to cloak harsh truths with innuendos. You cannot make great films if you suffer from constricting inhibitions of this sort."

American directors were well equipped with filmmaking tools and hence, one of Hollywood's strongest feature contradicts with British Cinema; thus, we can admit British Cinema as a part of World Cinema, only if we go by this description. But, not following the American style doesn't mean to leave out the better characteristics of the country, as well. Yes, one dearly needs to carry his own charm while dictating the medium of Cinema, but at the same time, being well-equipped is an advantage and shouldn't be advocated against globalization. Hereby, probing deeper, British Cinema had been a dummy of hypocrisy, where inability was intentionally confused with being technologically sound. In such a way, British Cinema can never be claimed as a part of World Cinema, as to make a quality work or Cinema, one needs the amalgamation of technology and creativity. Although, Orson Welles was a bit of exception and could be identified with any Hollywood filmmaker of the day. Or, we should say that the British intellectuals juggled up a 100-pages novel with a 70$\mathrm{mm}$ screened Cinema. They were definitely good theorists, although, filmmaking is altogether a different piece of cake.

\section{Did we talk of Alfred Hitchcock?}

Though, Alfred Hitchcock was an Englishman, he appeared more of an American extract, than being a British. Take any of his films, we can easily find a hint of Americano in that; stylish, sensuous, and most importantly, technically excellent. Hitchcock was one of the very first directors, who migrated to Hollywood or to say, he got lured away by the Movie Moguls. Hence, Alfred Hitchcock can be accepted as a Hollywood director as his contribution to Hollywood Cinema leads by a large fraction, if compared to British Cinema.

\subsection{Qualitative aspect of World Cinema}

World Cinema suggests the class of Cinema which can be accepted throughout the world due to a certain number of qualities:

- A crème layer of Cinema

- No-language barrier for the viewers

- Technical competence (least blemishes)

- A directorial excellence

- Classy enactments

- Most importantly, the identification factor, or cross cultural acceptance

Keeping in mind the above noted factors, I just want to ask you a one-liner.

\section{Which is the quality that Hollywood is deprived of? You will get the answer in the below lines.}

There is a contradiction in finding out the true measures to identify, what really World Cinema implies. Hollywood has been producing a crème strata of movies, since a long time, but the term 'Crème Layer' is itself very perceptive and means different to different people. To European and Asian filmmakers, crème Cinema refers to the intellectual kind of movies that are produced for a certain section of audience (which is quite less). But, Americans go for Vox-Pop while defining 'good-qualityCinema'. Vox-Pop in films, refers to the form of art that is acceptable to the majority. This expectedly fetches huge income, as well. In shorter words, Hollywood prefers good revenue earnings over critical appreciation. The same thing will be concluded in the next section.

\subsection{Commercialism, as a threat to World Cinema}

Quality cannot be equivalent to quantity. If a layman talks about the quality of a film, he is actually talking about its quantity, but not quality. Yes, perhaps this is true. The art of filmmaking includes a bulk of tedious effort as well as mental exertion. Each film is made with a definite motif or interpretation by the director (Auteur), which can be perceived by a viewer as he wishes, but the true meaning of the movie will not be extracted, wholly. Corresponding with a layman's taste, films are also being commercialized, which takes out the quality of the film. Revenues are there, film criticism has taken the form of film appreciation; all these methods are done to please the same layman, who is working six days a week, and rests himself on the last seat of a Cinema Theatre on Sundays. This is really a threat to World Cinema. 


\section{But how does this trend equates with Hollywood?}

In the era of globalization, U.S.A. predominantly leads the world, be it Cinema or business me (although, both are parallel to the Americans). The situation has worsened (it has got better, as per U.S.A.) and other countries are forcefully getting influenced by westernization or globalization, to say. Production brands like WB and EROS have entered international MARKETS of India and Europe, and earning a lot through film revenues. What it has done is, the quality of cinema have gained popularity, but good quality barely exists now. Although, there is no language barrier left throughout the world, one is deprived of crème layer of Cinema. No more the world is able to see the excellence of Truffaut, Goddard or Satyajit Ray, although a scarce fraction of intellectual films are still being made in places like India, Iran and France.

\section{Silent Era: First step to World Cinema}

The main motive of World Cinema has been to represent the world as a whole single entity. In that way, silent films have had played some role to initiate the concept of World Cinema, knowingly or unknowingly.

In the era when filmmaking began, technical incompetency was not apt for many match-able things; and among them all, recording sound was a significant field. Silent era represented films or the domain of Cinema that was made with lots of visual elements, but nothing to hear. As the usage of sound or even music could not be equipped at that time, silent films marked some brilliance in emotions, while acting. Be it a pro or con, acting was much more polished at that age as the mute actors had nothing but a face to express themselves. It can also be claimed as the pure usage of the medium, in Satyajit Ray's words.

\section{But, how did it lay the first step to World Cinema?}

As already mentioned, World Cinema lets no barrier come among the global audience; silent films had been in phenomenal in achieving the same thing. Without the usage of words, it becomes a bit easier to interpret the true sense of a film; the condition is, to showcase polished silent performances. Henceforth, the barrier of cross-cultural exchanges gets conveniently eliminated.

As per Satyajit Ray:

"It is not as if sound films do not contain moments of purely visual significance. But whenever they do, they inevitably hark back to the silent cinema. And more often than not they prove to be the moments that stay in the mind longest."

It has always been true that a maiden looking at her lover with fluid raged eyes, is a much more impressive display than a girl saying I love youto her beloved. Visual significances (more often, only displayed in silent films) have created a kind of empathy in a viewer's mind, be him a French, Dutch, or even an Indian. Now talking of (sound) World Cinema, even the trend set by Godard, is quite intentionally (and predominantly) a visual one. In Godard's Cinema, the dialogues are often banal and improvised.

\section{How can we end this section without talking about Charles Chaplin? The films crafted by Chaplin depict a literary experience, that too without sound.}

When Chaplin chews his shoes in GOLD Rush, he displays something which is not only comic but is also rich in overtones of symbolical meanings or motifs conceived by purely visual means. Such a scene could never have been conceived in literary terms. But when he involves himself in literary performances in films like Verdoux and Limelight, he conveys less sense in a purely less artistic manner than a single piece of 'acting' excellence done with the shoe in Gold Rush. The act done in Gold Rush would have been very easy and appealing to audience around the globe; but if we talk about hisliterary acting in Limelight, it might have not created an equivalent impact to the viewers who don't understand the language, to say English.

Thus, it can be easily derived that World Cinema got its initiation from the Silent Era of Cinema, when visual language did not let any other form of language dictate the art of Cinema.

\section{Conclusion}

World Cinema is almost like a fluid. The adjective applies for the spectrum of Cinema, be it commercial or parallel. Therefore, the term 'World Cinema' means different entities to different people.

People, I mean common people regard a film as being 'good' or 'bad' depending on the amount of identification it forms with the viewer. But, the real meaning of a film or the quality of a film stays with a critic.

The whole concept of World Cinema is something worth talking about. Although, such a debate might never end that what actually is a true example of World Movie. In this paper, justifications have been made, interpretations have been cleared, and even contradictions have been dealt with, still there would be the same kind of notions related with the term.

In this regard, what we need to do is to develop a sense of creative individuality to localize the sense of crème layer of Cinema. It's easy to get influenced by westernized perspectives, but it's time that we decide 
where we stand on our intellect. The easiest, (although, quite tough in today's global village era) and the most subtle way to create World Cinema is to talk about our own land, internationally. Or to say, to get international, one has to be immensely national. Only then, the barrier of language will soon get diminished with crosscultural expressions; else, Hollywood will bring along a standardized, and sophisticated form of commercial Cinema. It can be a visual delight, but the ethics of filmmaking gets gradually eroded. If we are able to do so, the sense of World Cinema will be established, truly.

\section{Acknowledgment}

I wish to thank Mr. Deb Chowdhury who first inculcated a strong inclination towards the medium that helped me conceive works of such high quality.

I would like to thank Dr. Debasish Chaudhuri for bearing with me through the period of gestation and any kind of blemishes present in this paper rest squarely on my shoulders.

Finally, a special word of thanks to my mother and my fiancée for inspiring me at every stage from inception to its emergence as a finished entity

[1]. Our Films, their films - Satyajit Ray

\section{References}

